\title{
Effect of Selected Tree Species on Maximizing Soil Organic Carbon Sequestration in Imo State, Nigeria
}

\author{
Umeojiakor A. O.", Egbuche C. T., Ubaekwe R. E., Nwaihu E. C. \\ Department of Forestry and Wildlife Technology, Federal University of Technology, Owerri, Nigeria
}

\section{Email address:}

heavenlytony@yahoo.com (Umeojiakor A. O.)

\section{To cite this article:}

Umeojiakor A. O., Egbuche C. T., Ubaekwe R. E., Nwaihu E. C.. Effect of Selected Tree Species on Maximizing Soil Organic Carbon Sequestration in Imo State, Nigeria. Agriculture, Forestry and Fisheries. Special Issue: Environment and Applied Science Management in a Changing Global Climate. Vol. 4, No. 3-1, 2015, pp. 40-45. doi: 10.11648/j.aff.s.2015040301.17

\begin{abstract}
The world is currently experiencing a period of warming and the role of soil carbon pools for mitigation of greenhouse gases has encouraged the need for more knowledge on the tree species effects on soil organic carbon. The study was conducted to evaluate the effect of tree species on maximizing soil organic carbon sequestration in Imo State, Nigeria. Four tree species (Teak, Tectona grandis, linn, Gmelina, Gmelina arborea Roxb, Rubber plant, Hevea bransiliensis Mull. Arg. and Black velvet, Dialium guineense Wild) were chosen for the study. Random soil sampling was used in field studies. Soil samples were collected at the depth of $0-15 \mathrm{~cm}$ and $15-30 \mathrm{~cm}$. these soil samples were prepared and subjected to routine laboratory analysis. Soil organic carbon sequestration was calculated and relationships between soil organic carbon sequestration and soil properties were obtained by simple correlation. Results showed that Tectona grandis of sequestration value 154.1 and 116.8 at top soil and subsoil respectively provides the best option for maximizing carbon sequestration in the soil, followed by Hevea bransiliensis (147.4 and 91.1), Gmelina arborea (134.1 and 81.1) and least was in Dialium guineese (108.1 and 60.1) at all depth. There was significant $(\mathrm{P}=0.01)$ positive correlation between base saturation, calcium, total nitrogen with soil organic carbon sequestration at $\mathrm{r}$-values of $0.77,0.74$ and 0.97 respectively. Hence, negative correlation existed between soil $\mathrm{pH}$, clay fraction potassium with soil organic carbon sequestration with r-values of $-0.37,-0.68$ and -0.54 respectively. It can be concluded that soil organic carbon sequestration decreases with decreasing depths and were greatly affected by tree species, soil properties and management practices.
\end{abstract}

Keywords: Tree Species, Soil Organic Carbon Sequestration, Soil Properties, Management Practices

\section{Introduction}

The world is currently experiencing a period of warning and it is widely accepted that the cause of this warming is a direct result of the increased levels of carbon dioxide $\left(\mathrm{CO}_{2}\right)$ in the atmosphere, caused by both natural and anthropogenic factors, such as industrial development, deforestation, agricultural improvements, increased use of cars and release of green house gases $\left(\mathrm{CH}_{4}, \mathrm{CO}_{2}, \mathrm{~N}_{2} \mathrm{O}\right.$, etc $)$ are the major contributing factors to the depletion of the ozone layer and its associated global warming and climate change. Carbon exists in many forms, predominantly as plant biomass, soil organic matter and as the carbon dioxide $\left(\mathrm{CO}_{2}\right)$ in the atmosphere. Soil especially the forest soil is one of the main sinks of carbon on earth because these soils normally contain higher soil organic matter. It has been propounded that one method to reduce atmospheric carbon dioxide $\left(\mathrm{CO}_{2}\right)$ is to increase the global storage of carbon in soils. Soils are the largest carbon reservoirs of the terrestrial carbon cycle. It contains twice the amount of carbon in the atmosphere as carbon dioxide and thrice the amount in global vegetation [1].

Interest in the ability of forest soils to sequester atmospheric carbon dioxide has increased because of the threat of projected climate change. Thus, understanding the mechanisms and factors of soil organic carbon dynamics in forest soils is important to identify and enhance natural sinks for carbon sequestration to mitigate the climate change. Soil carbon sequestration is the process of transferring carbon dioxide from the atmosphere into the long lived pools (soil) through plant residues and other organic solids, and in a form that is not immediately remitted [2]. Put simply, soil carbon sequestration involves the transfer of atmospheric carbon dioxide into soil organic carbon pool [3]. This transfer or "sequestering" of carbon helps off-set emissions from fossil fuel combustion and other carbon-emitting activities while 
enhancing soil quality and long-term agronomic productivity.

The role of soil carbon pools for mitigation of greenhouse gases has encouraged the need for more knowledge on the tree species effects on soil organic carbon. Forest management, including a change in tree species, has been accepted as a measure for mitigation of atmospheric carbon dioxide in national green house budgets [4]. Hence, carbon sequestration by forest plantations is being proposed as one method of positively affecting the balance of atmospheric levels of carbon dioxide. [5]; [6]. One of the most effective activities to improve soil carbon sequestration is choosing suitable forest tree species; unfortunately, there is limited knowledge of it [7]. Therefore, this study will aid us to understand the forest plantation that provides the best option for maximizing carbon accumulation in the soil in order to enhance the natural sink of green house gases, reduce the rate of soil organic carbon depletion there by reducing atmospheric carbon dioxide that contributes to global warming and climate change.

\section{Materials and Methods}

\subsection{Description of the Study Area}

The study was conducted in three different locations of four different forest plantations in Imo State, Imo state lies between latitude $4^{0} 45^{1}$ and $5^{0} 50^{1} \mathrm{~N}$ and longitude $6^{0} 35^{1}$ and $7^{0} 30^{1} \mathrm{E}$. The three locations of the plantations are Ohuba, Umudike - 11, both in Ohaji/Egbema Local Government Area, and Federal University of Technology Owerri (FUTO) in Owerri West Local Government Area in Imo State, southeastern Nigeria. It has a humid tropical climate, characterized by bimodal rainfall pattern with mean annual rainfall ranging from 1800 to $2500 \mathrm{~mm}$ and mean annual temperature ranging from $26^{\circ} \mathrm{C}$ to $31^{\circ} \mathrm{C}$ [8]. [9] showed that the underlying geological material are coastal plan sand (Benin Formation) and the Bende-Ameki formation. It consists of mainly friable sands with minor intercalations of clay.

\subsection{Selection of the Study Forest Plantations}

The study area consists of four forest plantations and they are as follows:

1) Gmelina arborea forest plantation site was established in the year 2004. It covers about five (5) hectares of land. The site was originally a fallow land, which was cleared through manual bush clearing followed by burning. After which, the seedlings of Gmelina arborea gotten from Ohaji/Egbema forest reserve was introduced to the site with $11 \times 17$ spacing. There is no special management practice such as beaten up, fertilization, pruning etc given to the growing seedlings except clearing of the weeds/bushes which is mainly Panicum maximum and few of chromoleana odorata. Fuel-wood harvesting and hunting were observed in the plantation. Presently, the trees have attained appreciable height and have a lot of plant debris on the floor.

2) Tectona grands forest plantation was established on the same land area of Gmelina arborea in the year 2004. It has the same management practices with Gmelina arborea. The only different is in their growth sizes.

3) Hevea brasilinensis plantation site of study was established in the year 1965 and was registered with the government in 1968. The site was originally a farmland under yam cultivation, before it was cleared through manual cuttings followed by bush burning. Then, hevea brasiliensis seedlings were collected from Federal Government and planted using 11 x 22 spacing in an area of about 6 hectares of land. Planted seedlings were raised with NPK fertilizer and other locally made compost, weeding, beaten-up were also observed. Presently the stands are well matured with fruits/seeds which falls and germinate thus alters the original spacing. Pruning, thinning, and bush clearing are always carried out in the site for maintenance purposes, also tapping of latex from about 15 years old plants and fetching of fuel-wood were also observed in the site.

4) Dialium guineense is a dominant tree species in a secondary forest beside River Otamiri in Federal University of Technology Owerri (FUTO). The area is characterized by mostly plant species, arranged in storey, with close canopies, highly depleted by anthropogenic activities such as fuel-wood harvesting, deforestation, hunting and gathering from wildlife.

\subsection{Soil Sampling Techniques}

Soil samples were randomly collected from each plantation at varying depths of $0-15 \mathrm{~cm}$ and $15-30 \mathrm{~cm}$ with an aid of soil auger. The soil samples were randomly collected at five different points in each plantation (five replicates). The collected soil samples were bagged in a polyethene bags and carefully labeled according to the plantation types, replicate number and depth. A total of forty (40) samples were collected from four forest plantations at two (2) varying depth. Core samples were also used to collect soils at each plantation in two (2) varying depths for bulk density determination. A total of eight (8) undisturbed core soil samples were carefully packaged and labeled accordingly.

\subsection{Laboratory Analysis}

The soil samples were air-dried at room temperature, crushed and sieved using $2 \mathrm{~mm}$ sieve. The composite soil samples were taken to the laboratory for determination of the physical and chemical properties. Particle size distribution was determined by hydrometer method [10]. Bulk density was determined by the core method using [11]. Textural class was determined by [12]. Soil $\mathrm{pH}$ was measured using $\mathrm{pH}$ meter [13]. Soil organic carbon was determined by the WalkleyBlack method described by [14]. Soil organic matter was determined by [15]. Total nitrogen was determined by the Kjeldahl method [16]. Available phosphorus was determined using Bray 1 method [17] Cation exchange capacity was 
obtained using the procedure described by [18]. Base saturation was calculated as total exchangeable bases divided by effective cation exchange capacity multiply by 100 percent.

\subsection{Data Analysis}

Data collected were statistically analyzed using Genstat Discovery ( $3^{\text {rd }}$ Edition). The relationship between soil carbon sequestration and soil properties were determined using simple linear correlation $(\mathrm{P} \leq 0.05)$ and $(\mathrm{P} \leq 0.01)$. Soil organic carbon sequestration was calculated according to [20].

Soil organic carbon sequestration $(\mathrm{SOCS})=\mathrm{BD}\left(\mathrm{g} / \mathrm{cm}^{3}\right) \mathrm{x}$ $\mathrm{SOC}(\mathrm{g} / \mathrm{kg}) \times$ soil depth $(\mathrm{cm})$

Where; $\mathrm{BD}=$ Bulk density

$\mathrm{SOC}=$ Soil organic

Carbon.

\section{Results}

Table 1 and 2 show the physical and chemical properties of the topsoil and subsoil in the four forest plantations of the study. The soils are generally sandy sand at $0-15 \mathrm{~cm}$ depth except for Dialium guineense which is sandy loam. At $15-$ $30 \mathrm{~cm}$ depth, soils of Tectona grandis and Dialium guineese are sandy loam with sand value of $784 \mathrm{gkg}^{-1}$ and $824 \mathrm{gkg}^{-1}$ respectively, and clay value of $156 \mathrm{gkg}^{-1}$. Gmelina arborea is sandy clay loam with sand value of $704 \mathrm{gkg}^{-1}$, clay value $276 \mathrm{gkg}^{-1}$. Hevea bransiliensis is loamy sand with sand value of $844 \mathrm{gkg}^{-1}$, and clay value $136 \mathrm{gkg}^{-1}$. However, [20], states that soil texture affects soil carbon sequestration due to its influence on soil microbial community and soil respiration.

Table 1. Soil Physical Properties of the Study Locations

\begin{tabular}{|c|c|c|c|c|c|c|}
\hline Plantation Site & Depth (cm) & Sand $(\mathrm{g} / \mathrm{kg})$ & Silt (g/kg) & Clay (g/kg) & Textural Class & Bulk Density $\left(\mathrm{g} / \mathrm{cm}^{3}\right)$ \\
\hline Gmelina arborea & $0-15$ & 844 & 60 & 96 & Sandy Sand & 0.868 \\
\hline Hevea branisiliensis & $0-15$ & 884 & 20 & 96 & Sandy Sand & 0.936 \\
\hline Tectona grandis & $0-15$ & 864 & 40 & 96 & Sandy Sand & 0.849 \\
\hline \multirow[t]{2}{*}{ Dialium guineense } & $0-15$ & 804 & 40 & 156 & Sandy Loam & 0.775 \\
\hline & Mean & 849 & 40 & 11 & Sandy Sand & 0.857 \\
\hline Gmelina arborea & $15-30$ & 740 & 20 & 276 & Sandy Clay Loam & 0.858 \\
\hline Tectona grandis & $15-30$ & 784 & 60 & 156 & Sandy Loam & 0.916 \\
\hline \multirow[t]{2}{*}{ Dialium guineense } & $15-30$ & 824 & 20 & 156 & Sandy Loam & 0.761 \\
\hline & Mean & 789 & 30 & 181 & Sandy Clay Loam & 0.84175 \\
\hline
\end{tabular}

Table 2. Soil Chemical Properties of the Study Locations

\begin{tabular}{|c|c|c|c|c|c|c|c|c|c|c|c|c|c|c|c|c|}
\hline Plantation & $\begin{array}{l}\text { Depth } \\
\text { (cm) }\end{array}$ & $\begin{array}{l}\text { pH } \\
\left(\mathrm{H}_{2} \mathrm{O}\right)\end{array}$ & $\begin{array}{l}\text { pH } \\
\text { (kcl) }\end{array}$ & $\begin{array}{l}\text { Org. } \\
\text { Carbon } \\
\text { (g/kg) }\end{array}$ & $\begin{array}{l}\text { Org. } \\
\text { Matter } \\
\text { (g/kg) }\end{array}$ & $\begin{array}{l}\text { Total } \\
\text { N } \\
(\mathrm{g} / \mathrm{kg})\end{array}$ & $\mathbf{C} / \mathbf{N}$ & $\begin{array}{l}\text { Avail. P } \\
\text { (mg/kg) }\end{array}$ & $\mathrm{Ca}$ & mg & $\begin{array}{l}\mathrm{K} \\
\mathrm{Cmol} / \mathrm{kg}\end{array}$ & $\begin{array}{l}\text { Exc } \\
\mathrm{Na}\end{array}$ & $\mathbf{H}$ & Al & CEC & BS \% \\
\hline Gmelina arborea & $0-15$ & 5.03 & 4.05 & 10.3 & 17 & 0.8 & 12.9 & 6.36 & 3.2 & 1.6 & 0.19 & 0.11 & 0.1 & 0.4 & 5.6 & 91 \\
\hline $\begin{array}{l}\text { Hevea } \\
\text { branisiliensis }\end{array}$ & $0-15$ & 4.47 & 3.64 & 10.5 & 18.2 & 0.9 & 11.7 & 3.61 & 2.4 & 1.6 & 0.24 & 0.14 & 0.3 & 0.4 & 5.08 & 86.2 \\
\hline Tectona grandis & $0-15$ & 5.05 & 4.05 & 12.1 & 21 & 1 & 12.1 & 2.75 & 3.2 & 1.6 & 0.09 & 0.26 & 0.4 & 0.2 & 5.75 & 89.5 \\
\hline \multirow[t]{2}{*}{$\begin{array}{l}\text { Dialium } \\
\text { guineense }\end{array}$} & $0-15$ & 5 & 4.1 & 9.3 & 16.2 & 0.8 & 11.6 & 0.95 & 2 & 1.2 & 0.16 & 0.07 & 0.3 & 0.8 & 4.53 & 75.7 \\
\hline & Mean & 4.89 & 3.96 & 10.55 & 18.1 & 0.88 & 12.08 & 3.42 & 2.7 & 1.5 & 0.17 & 0.15 & 0.28 & 0.45 & 5.24 & 85.6 \\
\hline Gmelina arborea & $15-30$ & 5.58 & 3.97 & 6.3 & 11.0 & 0.55 & 11.5 & 7.61 & 2.6 & 2 & 0.2 & 0.09 & 0.1 & 1 & 6 & 81.6 \\
\hline $\begin{array}{l}\text { Hevea } \\
\text { branisiliensis }\end{array}$ & $15-30$ & 4.36 & 3.76 & 7.3 & 12.7 & 0.6 & 12.2 & 6.82 & 2 & 1.2 & 0.29 & 0.11 & 0.2 & 0.7 & 4.5 & 80 \\
\hline Tectona grandis & $15-30$ & 4.63 & 3.8 & 8.5 & 14.8 & 0.7 & 12.1 & 5.42 & 2 & 1.2 & 0.12 & 0.23 & 0.2 & 0.8 & 4.55 & 78 \\
\hline $\begin{array}{l}\text { Dialium } \\
\text { guineense }\end{array}$ & $15-30$ & 5.25 & 4.38 & 5.3 & 9.3 & 0.4 & 13.3 & 0.86 & 1.2 & 0.8 & 0.26 & 0.12 & 0.5 & 0.3 & 3.18 & 74.8 \\
\hline
\end{tabular}

The bulk density of the soils differed among the forest plantations of study. The highest value of bulk density at $0-$ $15 \mathrm{~cm}$ depth was recorded on soils of Hevea bransiliensis $\left(0.936 \mathrm{~g} / \mathrm{cm}^{3}\right)$ and the least value was on Dialium guineense $\left(0.775 \mathrm{~g} / \mathrm{cm}^{3}\right)$. At $15-30 \mathrm{~cm}$ depth, the highest value of bulk density was recorded on soils of Tectona grandis $(0.916$ $\left.\mathrm{g} / \mathrm{cm}^{3}\right)$ while the least value was also on Dialium guineense $\left(0.761 \mathrm{~g} / \mathrm{cm}^{3}\right)$. The soils were acidic with $\mathrm{pH}$ value ranging from 4.36 - 5.58. It was observed that Hevea bransiliensis plantation is more acidic than others both in the topsoil (4.47) and subsoil (4.36). This may be attributed to the management practice in the Hevea bransiliensis plantation such as application of fertilizer. [21] observed that continuous application of fertilizers such as ammonium sulphate $\left(\mathrm{NH}_{4}\right)_{2} \mathrm{SO}_{4}$ and urea to improve soil fertility without lime decrease the $\mathrm{pH}$ of the soil. The organic matter content of the soils ranging from $(21-9.3 \mathrm{~g} / \mathrm{kg})$, Tectona grandis plantation recorded the highest values in the topsoil $(21 \mathrm{~g} / \mathrm{kg})$ as well as subsoil $(14.8 \mathrm{~g} / \mathrm{kg})$. Dialium guineense has the least values both in the topsoil $(16.2 \mathrm{~g} / \mathrm{kg})$ and subsoil $(9.3 \mathrm{~g} / \mathrm{kg})$. However, the higher organic matter level is very important in tropical countries because it is the benchmark upon which forest soil 
properties depends. It also plays important role in soil quality and enhances agricultural productivity and sustainability. The percentage base saturation of the soils were between (91 $74.8 \%$ ). Gmelina arborea plantation recorded the highest values both in the topsoil (91\%) and subsoil (81.6\%).
Dialium guineense has the lowest values both in the topsoil (75.7\%) and subsoil (74.8\%). The higher percentage base saturation recorded in Gmelina arborea plantation may be attributed to higher clay percentage composition of the Gmelina Arborea plantation.

Table 3. Soil Organic carbon sequestrations among the Plantations at Different Depths

\begin{tabular}{llll}
\hline Plantation Site & Age of Plantation & Depth & Soil Organic Carbon Sequestration $\left(\mathbf{g}^{2} / \mathbf{c m}^{2} / \mathbf{k g}\right)$ \\
\hline Gmelina arborea & 9 & $0-15$ & 134.1 \\
Hevea branisiliensis & 48 & $0-15$ & 147.4 \\
Tectona grandis & 9 & $0-15$ & 154.1 \\
Dialium guineense & 31 & $0-15$ & 108.1 \\
& & Mean & 135.93 \\
Gmelina arborea & 9 & $15-30$ & 81.1 \\
Hevea branisiliensis & 48 & $15-30$ & 91.1 \\
Tectona grandis & 9 & $15-30$ & 116.8 \\
Dialium guineense & 31 & $15-30$ & 60.5 \\
\end{tabular}

Table 4. Correlation between Soil Organic Carbon Sequestration and Soil Properties

\begin{tabular}{|c|c|c|}
\hline Soil properties & $\mathbf{R}$ & Level of Significance \\
\hline Available Phosphorus & -0.00576 & NS \\
\hline Bulk Density & 0.62044 & $*$ \\
\hline Cation exchange Capacity & 0.57173 & $*$ \\
\hline Base Saturation & 0.76891 & $* *$ \\
\hline $\mathrm{C} / \mathrm{N}$ ration & -0.27130 & NS \\
\hline Exch. Calcium & 0.73675 & $* *$ \\
\hline Exch. Hydrogen & -0.0870 & NS \\
\hline Exch. Potassium & -0.54498 & $*$ \\
\hline Exch. Magnesium & 0.42487 & NS \\
\hline Organic Carbon & 0.97556 & $* *$ \\
\hline $\mathrm{pH}\left(\mathrm{H}_{2} \mathrm{O}\right)$ & -0.37404 & NS \\
\hline Sand Fraction & 0.57081 & $*$ \\
\hline Total Nitrogen & 0.96684 & $* *$ \\
\hline
\end{tabular}

$*$ and $* *=$ significant at 0.05 and 0.01 probability levels respectively, NS $=$ non significant

\section{Discussion}

Soil organic carbon sequestrations among the plantations at different depths are shown in table 3 above. The result shows that the mean value of soil organic carbon sequestration was highest (135.93) within the topsoil (0-15) with Tectona grandis plantation exhibiting the highest value (154.1) followed by Hevea bransiliensis plantation (147.4), Gmelina arborea plantation (134.1) and least was in Dialium guineense of secondary forest (108.1). Within the subsoil (15 - 30), the mean value of soil organic carbon sequestration was (87.38) with Tectona grandis value reduces to (116.8), followed by Hevea bransiliensis plantation (91.1), Gmelina arborea plantation (81.1) and least was also in Dialium guineense of secondary forest (60.5). Hence, the soil organic carbon sequestration decreased with depth at all study sites. This is in agreement with earlier findings of [21]. Also, the results indicated that the age of the plantation is not related to its soil organic carbon sequestrations. Since Tectona grandis plantation of 9 years, which is one of the youngest plantation has the highest value (154.1) of soil organic carbon sequestration, Hevea bransiliensis plantation which is 48 years has the value of (147.4), Gmelina arborea plantation of 9 years has a value of (134.1) where as Dialium guineense in secondary forest of 31 years has the least value of (108.1). This is in accordance with similar findings by [22], where carbon change of the soil sampled below a depth of $10 \mathrm{~cm}$ in an afforested area, had no significant relationship with stand age.

Furthermore, the results indicated that tree species affects soil properties as well as soil organic carbon sequestration that is not only natural and anthropogenic factors as documented by [23]. It was observed in the plantations of Gmelina arborea and Tectona grandis that was established on the same land area, with the same climate factors, given the same management practices, in the same year, yet they sequester carbon differently, Tectona grandis (154.1) and Gmelina arborea (134.1). This supports the earlier findings by various authors as reported below: [24] states that one the most effective activities to improve soil carbon sequestration are choosing suitable forest tree species. The selection of tree species is one factor to consider if we want to mitigate 
carbon dioxide emissions to the atmosphere through forest management. [25], [26], [27]. Forest management including a change in tree species, has been accepted as a measure for mitigation of atmospheric carbon dioxide in national green house gas budgets. Moreover, the results of simple correlation analysis are shown in table 4, indicated strong positive correlation between soil organic carbon sequestration and Base saturation $(\mathrm{r}=0.76891, \mathrm{P}=0.01)$. This implies that soil organic carbon sequestration increases with increasing Base saturation. In the chemical properties of the soils shown in table 2, the least value of the base saturation was found in Dialium guineense of secondary forest $(75.7 \%$ and $74.8 \%)$ at $0-15 \mathrm{~cm}$ and $15-30 \mathrm{~cm}$ depth respectively. Dialium guineense also recorded the least value of soil organic carbon sequestration both in topsoil and subsoil. Again, the results indicated strong positive correlation between soil organic carbon sequestration and total Nitrogen $(r=0.96684, p=0.01)$ implying that soil organic carbon sequestration increases with increasing total Nitrogen. This is seen in the chemical properties of the soils, were Tectona grandis plantation has highest value of total Nitrogen $(1.0 \mathrm{~g} / \mathrm{kg})$ as well as soil organic carbon sequestration of $(154.1)$ at $0-15 \mathrm{~cm}$ depth. Dialium guineense in secondary forest with least value of soil organic carbon sequestration (108.1) and also has least value of total Nitrogen $(0.08 \mathrm{~g} / \mathrm{kg})$ at the same depth. At $15-30 \mathrm{~cm}$ depth, Tectona grandis plantation has also the highest value of soil organic carbon sequestration (116.8) and total Nitrogen $(0.07 \mathrm{~g} / \mathrm{kg})$, while Dialium guineense in secondary forest with least value of soil organic carbon sequestration (60.5) and also has least value of total nitrogen $(0.04 \mathrm{~g} / \mathrm{kg})$. However, the results indicated negative correlation between soil organic carbon sequestration and exchangeable potassium $(\mathrm{r}=$ 0.54498, $\mathrm{p}=0.05$ ) implying that soil organic carbon sequestration decreases with increasing exchangeable potassium. That is the higher the value of soil organic carbon sequestration the lower its exchangeable potassium. This is seen in the results of the chemical properties in table 2 above, while Tectona grandis plantation with the highest value of soil organic carbon sequestration (154.1 and 116.8), has the least value of exchangeable potassium $(0.09$ and $0.12 \mathrm{cmol} / \mathrm{kg})$ at $0-15 \mathrm{~cm}$ and $15-30 \mathrm{~cm}$ depth respectively.

\section{Conclusion}

Soil organic carbon sequestration varied among the four plantations of study with maximum concentration in the Tectona grandis plantation, followed by Hevea bransiliensis, Gmelina arborea plantation and least concentration was found in Dialium guineense of secondary forest. It was ascertained that individual tree species had influence on the rates of soil organic carbon sequestration. Hence, Tectona grandis tree species provides the best option for maximizing carbon sequestration in the soil. Also it was observed that soil organic carbon sequestration decreased with decreasing soil depths. The highest concentration was found within the topsoil as compared to subsoil in all the plantations, due to high concentration of humus at the topsoil layers, as a result of large amount of plant litter deposit at the topsoil surfaces etc. Furthermore, it was discovered that age of the individual tree species/plantations does not affect its soil organic carbon sequestration concentration. Hevea bransiliensis plantation of 48 years old should have the highest concentration of soil organic carbon sequestration, followed by Dialium guineense in secondary forest of 31 years old when compared with Tectona grandis and Gmelina arborea plantations of 9 years old. But reverse was almost the case. Tectona grandis plantation was highest in soil organic carbon sequestration concentration followed by Hevea bransiliensis, Gmelina arborea and least was Dialium giuneense. In addition, some activities in the plantations such as latex tapping as performed in Hevea bransiliensis plantation affects soil organic carbon sequestration according to earlier findings by [28]. The carbon sequestration decreased significantly at early stages of latex tapping which stabilizing during the continuous harvesting and finally increased when latex harvest ceased. Soil disturbances, deforestation, erosion, fuelwood harvesting, land degradation, leads to reduction in soil quality, decrease in soil organic matter which result in a decrease in soil organic carbon and sequestration.

\section{References}

[1] Peng, C. H., M. J. Apps, D. T. Price, I. A. Nalder, andD. H. Halliwell, (this volume), Simulating carbon dynamics along the Boreal Forest Transect Case Study (BFTCS) in Central Canada, 1, Model testing,Global Biogeochem. Cycles,12, this issue.

[2] Perry, M. Rick, E., Bricklemyer R., (2004). Soil Carbon sequestration in Agriculture. Farm management practices can affect greenhouse Gas Emissions. Montana State University. Ext Services.

[3] Powlson, D.S., A.P. Whitmore and K.W.T. Goulding, 2011. Soil Carbon Sequestration to Mitigate Climate Change. A critical re-examination to identify the true and the false. Eur. J. Soil Sci., 62:42 - 55 .

[4] Larsen, J.B., Nielsen, A.B., (2007). Nature-based Forest management - where are we going? Elaborating Forest Development types in and with practice. Forest Ecology and Management 238:107 - 117 .

[5] Barson. M.M., Giford, R.M., (1989). Carbon dioxide Sinks the Potential Role of tree Planting in Austraria. In Swain, D.J. (Ed) Greenhouse and Energy, CSIRO, Mebbourne, PP 433 - 443.

[6] Adger, W.N., Brown, K., (1994). Land Use and the Causes of Global warming, Wiley, Chichester, UK, $271 \mathrm{pp}$.

[7] Vesterdal L, Schmidt IK, Callesen I, Nilsson L.O. Gundersen P. (2008) Carbon and Nitrogen in Forest Floor and Mineral Soil Under Six Common European Tree Species. Forest Ecology and Management 255 (1): 35 - 48.

[8] Onweremadu, E.U., Okon, M.A., Ihem, E.E., Okuwa, J., Udoh, B.T. and Imadojemu, P. (2011). Soil Exchangeable Calcium Mapping in Central Southeastern Nigeria using Geographic Information System. Nigeria Journal of Agriculture, Food and Environment. June 7(2): $24-29$. 
[9] Ofomata, G.E.K. 1975. Relief. In: Ofomata, G.E.K. (ed.) Nigeria in maps: Eastern States, Ethiope Publishing House, Benin City. pp.25-26

[10] Gee, G.W. and Or D. (2002). Particle Size Analysis. In Dane, J.H. and G.C. Topps (eds). Methods of Soil Analysis. Part 4, Physical Methods. Soil Sci. Soc. An. Book Series No. 5, ASA and SSSA, Madison, WI. Pp. 255 - 293.

[11] Grossman, R.B. and T.G. Reinsch. (2002). Bulk Density. In Dane, J.H. and G.C. Topps (eds). Methods of Soil Analysis. Part 4, Physical Methods. Soil Sci. Soc. An. Book Series No. 5, ASA and SSSA, Madison, WI. Pp. $201-228$.

[12] Soil Survey Staff. 2006. Keys to Soil Taxonomy. $10^{\text {th }}$ ed. Washington (DC): Natural Resources Conservation Services, US Department of Agriculture. P 332.

[13] Hendershot, W.H., Lalande, H. and Duguette, M. (1993). Soil Reaction and Exchangeable acidity. In Carter, M.R. (ed). Soil Sampling and Methods of Soil Analysis. Can Soc Soil Sci, Lewis pub. London. Pp. $141-145$.

[14] Nelson, D. W. and Sommers L.E. (1996). Total Carbon, Organic Carbon and Organic Matter. Methods of Soil Analysis Part 3. Chemical Methods (ed. By D.L. Sparks), pp. 961 1010. American Society of Agronomy, Madison, W.L.

[15] Baldock, J.A. and Skyemstad, J.O. (1999). Soil Organic Carbon/Soil organic Matter. In 'Soil Analysis': an Interpretation Manual (Eds K.I. Peverill, L.A. Sparrow, and D.J. Reuter) Pp 159 - 170 (CSIRO Publishing: Colling Wood).

[16] Udo, E.J, Ibia, T.O., Ogunwale, J.A., Ano, A.O. and Esu, I.E. (2009). Manual of Soil, Plant and Water Analysis. Sibon Books Ltd, Flat 15 blk 6. Fourth Avenue Festac, Lagos.

[17] Bray, R.H and Kurkz I.T. (1945). Determination of Total
Organic and Available forms of Phosphorus in Soil. Soil Science. J. 59:39-45.

[18] Soil Survey Staff. 2003. Keys to soil Taxonomy Ninth edition United State Department of Agriculture 332 pp.

[19] Davidson E.A., Belk, B. and Boone, R.D. (1998). Soil Water Content and Temperature as Independent or Confounded factors Controlling Soil Respiration in Temperate Mixed Hardwood Forest, Global Change boil, 4:217 - 227.

[20] Batjes, N.H., (1996). Total Carbon and Nitrogen in the Soils of the World Eur. J. Soil Sci. 47:151 - 163.

[21] Vesterdal L, Schmidt IK, Callesen I, Nilsson L.O. Gundersen P. (2008) Carbon and Nitrogen in Forest Floor and Mineral Soil Under Six Common European Tree Species. Forest Ecology and Management 255 (1): 35 - 48.

[22] Johnson, D.W. (1992). Effect of Forest Management on Soil Carbon Storage. Water, Air and Soil Pollution 64:83-120.

[23] De Wit, H.A. and Kvindesland, S. (1999). Carbon Stocks in Norwegian Forest Soils and Effect of Forest Management on Carbon Storage. Rapport Fra Skogforskningen, Supplement 14, norsk Institute for Skogforskining (NISK). 52p.

[24] Eviksson, E., Gillespie, A., Guestavesson, L., langvall, O., Olsson, M., Sathre, R. and Stendahl, J. (2007). Integrated Carbon Analysis of Forest Management Practices and Wood Substitution. Canadian Journal of Forest Research 37(3): 671 -681 .

[25] Yang, Y.S., Guo, J.F., Chen, G.S., Xie, J.S., Zhen, L., Zhao, J., 5005. Carbon and Nitrohen Pools in Chinese Fir and Evergreen Broadleaved Forests and Changes Associated with Delling and Burning in Mid-subtropical China. Forest Ecol. Manage. 216 (1-3), $216-226$. 